\title{
Post-harvest evaluation of tomato genotypes with dual purpose
}

Joicy Vitória Miranda PEIXOTO ${ }^{1 *}$, Lismaíra Gonçalvez Caixeta GARCIA ${ }^{2}$, Abadia dos Reis NASCIMENTO ${ }^{2}$, Emmerson Rodrigues de MORAES 3 , Tânia Aparecida Pinto de Castro FERREIRA², Marinete Rocha FERNANDES², Vanessa de Almeida PEREIRA²

\begin{abstract}
The objective of this study was to characterize and select genotypes which displayed aptitude for genetic improvement for tomatoes consumed in natura as well as for those used in industrial processing. There were ten genotypes evaluated, being those from seven lines (CVR 1, CVR 3, CVR 4, CVR 5, CVR 8, CVR 21 and CVR 22) and three commercial hybrids (AP-533, SVR-0453 and Kátia) and analyzing the physicochemical characteristics of the produced fruits as: soluble solids rates, acidity in citric acid, total titratable acidity, soluble solids and total titratable acidity relation, $\mathrm{pH}$, vitamin $\mathrm{C}$, mass, transversal and longitudinal diameter and fruit firmness. In face of the analyzed characteristics, it was concluded that all genotypes produce fruits with aptitude to be consumed in natura. The fruits present soluble solids content above $3^{\circ}$ Brix, oblong shape and "moderately soft" texture. Line CVR 22 showed the highest values for soluble solid and total titratable acidity relation, producing fruit with more pleasant and mild flavor, while lines CVR 3 and CVR 8 produced fruits with higher acidity and lower $\mathrm{pH}$, with red coloration accentuated, characteristics indicated for genetic improvement of industrial tomato.
\end{abstract}

keywords: Solanum lycopersicum L.; quality; genetic improvement; genotypes.

Practical Application: This work showed that all the analyzed genotypes have aptitude for in natura consumption, because the fruits produced have a soluble solids content above $3{ }^{\circ} \mathrm{Brix}$, oblong shape and "moderately soft" texture. The lines CVR 3 , CVR 8 and CVR 22 are indicated for the improvement of industrial tomato.

\section{Introduction}

Tomato crop is expressive in an economic and social way, as well nationally or internationally. This is the second most produced vegetable in the world, with relevant participation in human diet (Barankevicz et al., 2015). The fruit is considered as a source of carotenoids, especially $\beta$ carotene and lycopene, vitamins $\mathrm{A}, \mathrm{B} 1, \mathrm{~B} 2, \mathrm{~B} 5$ and $\mathrm{C}$, fibers and minerals, besides its low caloric power (Alvarenga \& Coelho, 2013).

High quality fruit production depends on environmental factors such as light and weather, besides farming practices, and genetic variability among the materials is a strategy for crop improvement (Causse et al., 2003). Horticultural products quality is associated with its integrity, flavor and texture, interrelated to other physical, chemical and nutritional properties (Chitarra \& Chitarra, 2005). Quality and quantity attributes such as sugar quantity, soluble solid rates, acidity, $\mathrm{pH}$ and firmness are common in tomatoes consumed in houses and also for the fruits directed to industrial processing, and they may be compared between progenies (Quilot-Turion \& Causse, 2014).

Fruit shape and size, as well as its firmness, pericarp thickness, humidity rate, juice viscosity, soluble solid and total titratable acidity relation promote variations on physicochemical and nutritional

quality of tomato product fruit (Siddiqui et al., 2015). According to Riahi et al. (2009), Ilahy et al. (2011), Domínguez et al. (2012) quality attributes like fruit color and firmness, $\mathrm{pH}$, titratable acidity, soluble solids, vitamin C, lycopene, phenolic compounds, are dependent of the cultivar. Other factors which influence those variables are environmental conditions, fertilization, agronomic practices of farming and after-harvest storage (Barrett et al., 2007; Rosales et al., 2011; Beckles, 2012; Alvarenga \& Coelho, 2013).

High consumer demands and competition imposed by globalized market have forced the production of food with high nutritional standards, as well as improved sensorial and quality characteristics. Fruit and vegetable's quality can be characterized by attributes such as aspect, flavor, texture, nutritional value and food safety (Rocha et al., 2013).

The selection of cultivars is important in order to obtain resistant products with desirable aspect. Those, when submitted to different farming conditions vary in shape, size, color and in their capacity in reaching the desired phenotype (Chitarra \& Chitarra, 2005). Knowing the lines characteristics assists in predicting the hybrid quality regarding fruit firmness and composition (Causse et al., 2003). 
With that in mind, the objective of this study was to characterize and select lines through physicochemical characteristics of the fruit, with aptitude for crop improvement in tomato plants for industrial and in natura consumption.

\section{Materials and methods}

Ten industrial tomato plant materials were selected regarding plant sanity, ripening and visual quality of the fruits, followed by tomato's physicochemical analysis. The selected lines were CVR 1 , CVR 3, CVR 4, CVR 5, CVR 8, CVR 21 and CVR 22 and also the hybrids AP-533, SVR-0453 and Kátia. These materials were cultivated in the Escola de Agronomia at Universidade Federal de Goiás in 2014, located at $16^{\circ} 35^{\prime} 48^{\prime \prime} \mathrm{S}$ and $49^{\circ} 16^{\prime} 53^{\prime \prime} \mathrm{W}$, and at an altitude of $709 \mathrm{~m}$.

The soil of the area was characterized as having medium texture, as is categorized as a dystrophic Oxisol (Empresa Brasileira de Pesquisa Agropecuária, 2013). The soil macronutrients content was $3.9 \mathrm{cmolc} \mathrm{dm}^{-3}$ of calcium and $1.5 \mathrm{cmolc} \mathrm{dm}^{-3}$ of magnesium, $155 \mathrm{mg} \mathrm{dm}^{-3}$ of potassium, $19.4 \mathrm{mg} \mathrm{dm}^{-3}$ of phosphorus (Melich) and $3.4 \mathrm{mg} \mathrm{dm}^{-3}$ of sulfur. The amount of micronutrients present in the soil was: $z i n c=8.7 \mathrm{mg} \mathrm{dm}^{-3}$, boron $=0.23 \mathrm{mg} \mathrm{dm}^{-3}$, copper $=4.1 \mathrm{mg} \mathrm{dm}^{-3}$, iron $=41.7 \mathrm{mg} \mathrm{dm}^{-3}$ and manganese $=25.1 \mathrm{mg} \mathrm{dm}^{-3}$. The cation exchange capacity at pH 7.0 was 8.33 , base saturation of $68.74 \%$ and organic matter of $22.0 \mathrm{~g} \mathrm{dm}^{-3}$. The $\mathrm{pH}$ in $\mathrm{CaCl}_{2}$ was 5.6 and the aluminum content of $0.0 \mathrm{cmolc} \mathrm{dm}^{-3}$ and $\mathrm{H}+\mathrm{Al}$ of $2.6 \mathrm{cmolc} \mathrm{dm}^{-3}$.

The climate of the region following the Köppen classification is Aw, characterized as Tropical Humid, and has two well-defined seasons, cold dry winter and rainy hot summer. The average precipitation from July to October, period of conduction of the experiment, was $28.42 \mathrm{~mm}$, the average temperature was of $24^{\circ} \mathrm{C}$ and the relative humidity was $59.5 \%$. Irrigation was done by means of drip irrigation according to evapotranspiration of the crop according to Doorenbos \& Kassam (1979).

The chemical variables analyzed were soluble solid rates (SS), citric acid acidity (CAA), total titratable acidity (TTA), soluble solids and total titratable acidity relation (SS/TTA), $\mathrm{pH}$ and vitamin $\mathrm{C}$. The physical characteristics were color, mass, transversal diameter (TD), longitudinal diameter (LD) and fruit firmness.

All fruits were harvested in their highest ripening levels. They were emerged in water with sodium hypochlorite $50 \mathrm{ppm}$ for 15 minutes, in order to disinfect. Subsequently, they were drained and dried with paper towels. The amount of 20 tomatoes were kept in natura, ten for acidity determination, $\mathrm{pH}$, vitamin c and SS (done by triplicates), and ten tomatoes for peel color (hexaplicate analysis) and texture (quadruplicate analysis) analysis.

The levels of SS, TTA, SS/TTA relation and $\mathrm{pH}$ were determined according to methodology described by Association of Official Analytical Chemists (2010). Vitamin C quantity was quantified by the potassium iodate method, according to Instituto Adolfo Lutz (2008).

Color determination were performed by the reading of three parameters defined by the system $\operatorname{CIEL}^{\star} a^{*} b^{\star}$. Parameters $L^{*}, a^{*}$ and $\mathrm{b}^{\star}$ were supplied by colorimeter (Hunterlab, ColorQuest II), where $L^{\star}$ defines light $\left(L^{*}=0\right.$ black and $L^{*}=100$ white $)$ and $\mathrm{a}^{\star}$ and $\mathrm{b}^{\star}$ define chromaticity $\left(+\mathrm{a}^{\star}=\right.$ red and $-\mathrm{a}^{\star}=$ green, $+\mathrm{b}^{\star}=$ yellow and $-\mathrm{b}^{\star}=$ blue). The value of Chroma $\left(\mathrm{C}^{\star}\right)$ consisting of color saturation was obtained by the following Equation 1.

$c^{*}=\sqrt{\left(a^{*}\right)^{2}+\left(b^{*}\right)^{2}}$

The measurements were made in six points per fruit in a total of ten tomato fruits per experimental unit according to Jarquín-Enríquez et al. (2013).

Tomato mass and diameter determinations were taken in 15 fruits per treatment. Those were weighted on precision scales (model AY220, Marte), with four decimal digits after the comma. Diameter measuring was done in millimeters with the use of a digital caliper (STARFER/DIGITAL VERNIER CALIPER IVE0-150MM) in the median part of the fruit for transversal diameter and in its length for longitudinal diameter.

Texture was determined with the help of a texture analyzer (Texture Analyser TATXTi-Plus, Brokfield, Surrey, Inglaterra or EUA) and the software Texture Exponent lite version 4.0.13.0, through measuring firmness by the highest compression using destructive penetration (Bourne, 2002). The probe used was the penetration probe with round tip (Stainless $\mathrm{P} / 5 \mathrm{~S}$ ). The equipment height was of $59 \mathrm{~mm}$ and the perforation speed pre and post-test was $2 \mathrm{~mm} \mathrm{~s}^{-1}$ with compression distance of $20 \mathrm{~mm}$, cargo cell of $50 \mathrm{~kg}$ and probe geometry of $5 \mathrm{~mm}$.

Firmness was measured in a sample of ten fruits per treatment. The tomato was marked in a cross shape from its stem, $3.5 \mathrm{~cm}$ to each side, avoiding to touch the septum which divides the lobes. Perforations were done in all four marks and, according to the pressure applied by the equipment to pierce the fruit's stem, the force applied was obtained and, consequently, the fruit firmness.

Data obtained through the evaluations were tabulated and submitted to variance analysis (ANOVA) and applied the F test. The averages comparison was performed through the Scott-Knott test at 0.05 probability.

\section{Results and discussion}

Fruits produced in the line CVR 22 and by the hybrid Kátia, when compared to the other genotypes, presented higher levels of SS and highest SS/TTA ratio (Table 1). The lines CVR 4, CVR 5 and CVR 21 presented the lowest SS content when compared to the other genotypes. Line CVR 8 presented higher percentage of CAA and also TTA, with fruits with the lower $\mathrm{pH}$. Fruits from the line CVR 1, CVR5 and the hybrid AP-533 have denoted bigger amounts of vitamin C. Genetic constitution of tomato cultivars may have influence over the chemical and nutritional properties (Erba et al., 2013; Kavitha et al., 2014; Doménech-Carbó et al., 2015), which was observed in the results obtained in the study.

Sucrose and fructose constitute approximately $65 \%$ of the total soluble solids present in tomato. These sugars accumulate at the end of the fruit's maturation phase (Gautier et al., 2008; Alvarenga \& Coelho, 2013). The materials which present fruits with SS levels above three ${ }^{\circ}$ Brix may have their production commercialized in the in natura fruit market (Schwarz et al., 2013). 
Table 1. Chemical and nutritional parameters in tomato genotypes.

\begin{tabular}{|c|c|c|c|c|c|c|}
\hline Genotypes $^{2}$ & SS $\left({ }^{\circ} \text { Brix }\right)^{1}$ & $\mathrm{CAA}(\%)^{1}$ & TTA $(\%)^{1,3}$ & Ratio (SS/TTA) $)^{1}$ & $\mathrm{pH}^{1}$ & Vitamin C (mg of AA $100 \mathrm{~g}^{-1}$ of fruit) \\
\hline CVR 1 & $4.97 \mathrm{~b}$ & $0.47 \mathrm{c}$ & $0.73 \mathrm{c}$ & $6.82 c$ & $4.39 \mathrm{~d}$ & $26.42 \mathrm{a}$ \\
\hline CVR 3 & $4.73 \mathrm{c}$ & $0.48 \mathrm{~b}$ & $0.76 \mathrm{~b}$ & $6.19 \mathrm{e}$ & $4.30 \mathrm{~b}$ & $22.01 \mathrm{~b}$ \\
\hline CVR 4 & $4.53 \mathrm{~d}$ & $0.45 \mathrm{~d}$ & $0.72 \mathrm{c}$ & $6.36 \mathrm{~d}$ & $4.38 \mathrm{~d}$ & $20.10 c$ \\
\hline CVR 8 & $4.90 \mathrm{~b}$ & $0.54 \mathrm{a}$ & $0.84 \mathrm{a}$ & $5.83 \mathrm{f}$ & $4.24 \mathrm{a}$ & $19.08 \mathrm{c}$ \\
\hline CVR 21 & $4.53 \mathrm{~d}$ & $0.45 \mathrm{~d}$ & $0.71 \mathrm{c}$ & $6.43 \mathrm{~d}$ & $4.33 \mathrm{c}$ & $16.58 \mathrm{~d}$ \\
\hline SVR-0453 & $4.73 \mathrm{c}$ & $0.46 \mathrm{~d}$ & $0.72 \mathrm{c}$ & $6.60 \mathrm{c}$ & $4.46 \mathrm{e}$ & $21.72 \mathrm{~b}$ \\
\hline Kátia & $5.13 \mathrm{a}$ & $0.43 \mathrm{e}$ & $0.67 \mathrm{~d}$ & $7.58 \mathrm{a}$ & $4.38 \mathrm{~d}$ & $14.09 \mathrm{~d}$ \\
\hline $\mathrm{CV}(\%)$ & 1.87 & 1.64 & 1.95 & 2.32 & 0.33 & 9.88 \\
\hline W & 0.15 & 0.28 & 0.01 & 0.75 & 0.07 & 0.22 \\
\hline F & 0.002 & 0.02 & 0.08 & 0.21 & 0.005 & 0.008 \\
\hline
\end{tabular}

${ }^{1}$ averages followed by the same letter on the column do not differ between each other by Scott-Knott test at $5 \%$ probability; ${ }^{2}$ lines CVR Plant Breeding Ltda. Experimental hybrids (AP-533, SVR-0453: Seminis do Brasil and Kátia: Hazera Seeds); ${ }^{3}$ Data transformed by the arc sine $\sqrt{ }(\mathrm{X} / 100)$. W, F: presupposition from tests Shapiro-Wilk and Levene, values in bold indicate residue with normal distribution and homogeneous variation. $\mathrm{SS}=$ soluble solids; $\mathrm{CAA}=$ citric acid acidity; TTA= total titratable acidity; $\mathrm{AA}=$ ascorbic acid.

In this study, all genotypes presented fruits with SS levels above three ${ }^{\circ}$ Brix, and they can be commercialized in natura.

Industrial tomatoes must have levels of SS of at least 5 ${ }^{\circ} \mathrm{Brix}$ (Cemeroglu et al., 2003). The SS level is directly associates with industrial yield, where each ${ }^{\circ} \mathrm{Brix}$ of increment in the raw material has, on average, 10 to $20 \%$ of increase in yield (Boiteux et al., 2012). In this study, the hybrid Kátia and the line CVR 22 presented levels above this value, with $5.13^{\circ}$ Brix and $5.10^{\circ}$ Brix, respectively.

Concerning CAA (Table 1) a difference $(\mathrm{p}<0.01)$ was observed between the lines CVR 8 and and the other evaluated genotypes. The CVR 8 line presented fruits with presented the highest quantity of citric acid, with value of $0.54 \%$. The hybrid Kátia presented fruits with the lowest CAA $(0.43 \%)$.

For TTA (Table 1), a difference was verified $(\mathrm{p}<0.01)$ between the analyzed genotypes. The CVR 8 line presented the fruits with the highest ATT (0.84\%) when compared to the other genotypes. This line fruits have shown higher amounts of CAA incrementing TTA levels. It was observed that fruits from line CVR 22 and of the AP-533 and Katia hybrids presented the lowest TTA percentages, being $0.65 \%, 0.65 \%$ and $0.67 \%$, respectively.

The acidity present in tomato fruit influences its flavor and also the products resulting from it. The acid with higher levels in tomatoes is the citric acid (Anthon et al., 2011; Anthon \& Barrett, 2012). Silva et al. (2013), evaluating tomato for in natura consumption, observed levels of citric acid in $0.36 \%$ ( $0.36 \mathrm{~g}$ of citric acid in $100 \mathrm{~g}$ of fruit). Gatta et al. (2015) have noticed a CCA variation of $0.29 \%$ to $0.33 \%$ in fresh 'Manyla' tomato juice. The citric acid levels found in this study were all higher than the ones observed by these authors, indicating fruits with elevated acidity. It reflects in the processing industry, decreasing the heating period necessary to sterilize the product (Soares \& Rangel, 2012) and, consequently, reduces production costs. Tomato fruits with citric acid values below $0.35 \%$, require increase in processing time and temperature, to avoid the proliferation of microorganisms in the processed products (Silva et al., 2003).
A difference $(\mathrm{p}<0.01)$ was verified (Table 1$)$ in the relation of SS and TTA between the analyzed genotypes. Fruits produced by the line CVR 22 and by the hybrid Kátia showed the highest values for the relation, being these of 7.79 and 7.58 , respectively. The CVR 8 , when compared to the other genotypes, presented the fruits with the lowest SS/ATT ratio, being 5.83.

High values of SS/TTA relation appoint to mild flavor fruits. This is due to an optimum combination between acid and sugar. In contrast, fruits with low relation between those variables have more acid and, consequently, undesirable flavor (Ferreira, 2004). In this study, the line CVR 22 and the hybrid Kátia have produced fruits with lower acidity and higher quality. The fruits of these genotypes had the highest SS content, best SS/ATT ratio, red color implying high lycopene content, oblong shape and intermediate firmness.

Tigist et al. (2013) have observed SS/TTA relation of 5.5 in three varieties of tomato for industrial processing. While for the other six tomato varieties for in natura consumption had variation of 5.4 to 5.9. In this study, practically all genotypes have presented fruits with higher values for this relation, which implicates in more flavorful and high quality fruits.

Regarding $\mathrm{pH}$ (Table 1 ) a difference was verified $(\mathrm{p}<0.01)$ between the evaluated genotypes. Line CVR 8 has produced fruits with $\mathrm{pH}$ of 4.24 , with this value being lower than the other genotypes evaluated. The genotype CVR 22 presented the fruits with the highest $\mathrm{pH}$ (4.49).

Tomato fruits usually have enough acidity to maintain their $\mathrm{pH}$ bellow 4.6, and for that reason they are considered as acid food (Anthon \& Barrett, 2012). Gatta et al. (2015) have stated that in 'Manyla' tomato cultivar, the $\mathrm{pH}$ variation was from 4.50 to 4.58 . Figàs et al. (2015) evaluating 69 tomato accesses, have observed that the average $\mathrm{pH}$ was 4.24 . These numbers corroborate with the ones found in this study, where all $\mathrm{pH}$ values were below 4.6 . 
There is a inverse relation between TTA and $\mathrm{pH}$, where the higher the TTA, the lower the $\mathrm{pH}$ (Anthon \& Barrett, 2012) and vice-versa. In this study it was observed that the fruits of the CVR 8 line showed the highest CAA and TTA and the lowest $\mathrm{pH}$, with values of $0.54 \%, 0.84 \%$ and 4.24 , respectively (Table 1 ). In the genotypes CVR 22 and AP-533 lower percentages were obtained regarding CAA and TTA, both with rates of $0.42 \%$ for the first variable and $0.65 \%$ for the second. These are among the genotypes with higher $\mathrm{pH}$ levels, of 4.49 for CVR 22 and 4.40 for AP-533. The results observed by Anthon et al. (2011) and Doménech-Carbó et al. (2015) corroborate to those found in this study, where as the $\mathrm{pH}$ increases, TTA reduces.

In genetic improvement of industrial tomato plant, total acidity and $\mathrm{pH}$ are important characteristics and total acidity (citric acid must be over $0.35 \%$ and $\mathrm{pH}$ under 4.3 ). Acidity levels kept in these values enable higher processed pulp quality, avoiding proliferation of microorganisms such as Clostridium pasteurianum and Clostridium butyricum (Boiteux et al., 2012). In this study, the only genotype that met both characteristics, citric acid must be over $0.35 \%$ and $\mathrm{pH}$ under 4.3 , was line CVR 8 (Table 1).

A difference $(\mathrm{p}<0.01)$ was observed (Table 1$)$ regarding the levels of vitamin $\mathrm{C}$ (ascorbic acid) between the analyzed genotypes. The lines CVR 1 and CVR 5 and hybrid Kátia presented fruits with the highest levels of vitamin $\mathrm{C}$, being $26.42 \mathrm{mg}$ of AA $100 \mathrm{~g}^{-1}$ of fruit, $24.37 \mathrm{mg}$ of AA $100 \mathrm{~g} \mathrm{~g}^{-1}$ of fruit and $25.83 \mathrm{mg}$ of AA $100 \mathrm{~g}^{-1}$ of fruit, respectively. The genotypes CVR 21 (16.58 mg of AA $100 \mathrm{~g}^{-1}$ of fruit) and Katia (14.09 mg of AA $100 \mathrm{~g}^{-1}$ of fruit) presented fruits with the lowest amount of vitamin C.

Total vitamin C (ascorbic acid + dehydroascorbic acid) varies between species, cultivars and tissues. Those variations between genotypes are influenced by environmental and cultural factors and storage conditions (Chitarra \& Chitarra, 2005). Ilahy et al. (2011), Mohammed et al. (2012), Domínguez et al. (2012), Doménech-Carbó et al. (2015), as well this study, have observed differences $(\mathrm{p}<0.01)$ in ascorbic acid levels between the different studied cultivars.

Vitamin C levels normally observed in in natura tomatoes are between 15 and $23 \mathrm{mg}$ of AA $100 \mathrm{~g} \mathrm{~g}^{-1}$ of fruit, with normal interval of 8.4 and $59 \mathrm{mg}$ of AA $100 \mathrm{~g} \mathrm{~g}^{-1}$ of fruit (Dumas et al., 2003). Alvarenga \& Coelho (2013) stated that $100 \mathrm{~g}$ of the ripe in natura tomato fruit contains about 18 to $40 \mathrm{mg}$ of AA $100 \mathrm{~g}^{-1}$ of fruit. Silva et al. (2013) observed that in the Santa Clara 5800 cultivar, the average of vitamin C is of $33.65 \mathrm{mg}$ of AA $100 \mathrm{~g} \mathrm{~g}^{-1}$ of fruit, while Ramos et al. (2013) found $55 \mathrm{mg}$ of AA $100 \mathrm{~g}^{-1}$ of fruit in the Giuliana hybrid. In the present study, only the genotypes Kátia and CVR 21 presented fruits with vitamin C levels below $18 \mathrm{mg}$ of AA $100 \mathrm{~g}^{-1}$ of fruit, with $14.09 \mathrm{mg}$ of AA $100 \mathrm{~g} \mathrm{~g}^{-1}$ of fruit and $16.58 \mathrm{mg}$ of AA $100 \mathrm{~g} \mathrm{~g}^{-1}$ of fruit, respectively. The other genotypes have demonstrated level within normal, oscillating between $18.20 \mathrm{mg}$ of AA $100 \mathrm{~g} \mathrm{~g}^{-1}$ of fruit and $26.42 \mathrm{mg}$ of AA $100 \mathrm{~g}^{-1}$ of fruit.

Fruit color is one of the most important parameters observed by the consumer and what characterizes product vitality. A difference $(\mathrm{p}<0.01)$ was verified (Table 2$)$ between the analyzed genotypes regarding the coordinate "chromaticity $\mathrm{a}^{*}$, which varies from -60 (green) to +60 (red), "chromaticity $b^{* ”}$, varying from -60 (blue) to +60 (yellow), $L^{*}$ parameter, indicating luminosity and with variation from 0 to 100 and for Chroma $\left(C^{\star}\right)$.

The $\mathrm{C}^{\star}$ value provides a proportion of the pure predominant tone and concern the perception of the difference given a color relatively to white or gray, with opaque tones close to zero and with more lively to those close to 60 (Preczenhak et al., 2014). The higher the value for the chroma parameter, the more saturated and intense is the color of the fruit (Borguini \& Silva, 2005).

The fruits of the CVR 3 and CVR 22 lines and the hybrids Kátia and AP-533 (Table 2) showed a more intense red color, presenting the highest value for the parameter $\mathrm{a}^{*}$, when compared to the other genotypes which presented less intense coloration. The line CVR 5 presented the less intense color, indicating lower levels of lycopene.

Table 2. Average values of the parameters $\mathrm{a}^{\star}, \mathrm{b}^{\star}, \mathrm{L}^{\star}$, and chroma $\left(\mathrm{C}^{\star}\right)$ of different materials of industrial tomato.

\begin{tabular}{|c|c|c|c|c|}
\hline Materials $^{2}$ & $a^{* 1}$ & $\mathrm{~b}^{* 1}$ & $\mathrm{~L}^{\star 1}$ & $\mathrm{C}^{\star 1}$ \\
\hline CVR 1 & $30.26 \mathrm{~b}$ & $30.22 \mathrm{~b}$ & $32.47 \mathrm{~b}$ & $44.48 \mathrm{c}$ \\
\hline CVR 3 & $32.89 \mathrm{a}$ & $25.42 \mathrm{c}$ & $23.64 \mathrm{~d}$ & $34.77 \mathrm{~d}$ \\
\hline CVR 4 & $31.40 \mathrm{~b}$ & $27.34 \mathrm{c}$ & $23.32 \mathrm{~d}$ & $36.06 \mathrm{~d}$ \\
\hline CVR 5 & $25.99 \mathrm{c}$ & $33.00 \mathrm{a}$ & $28.74 \mathrm{c}$ & $43.82 \mathrm{c}$ \\
\hline CVR 8 & $31.32 \mathrm{~b}$ & $27.38 \mathrm{c}$ & $21.26 \mathrm{~d}$ & $34.71 \mathrm{~d}$ \\
\hline CVR 21 & $29.84 \mathrm{~b}$ & $32.67 \mathrm{a}$ & $30.74 \mathrm{~b}$ & $44.91 \mathrm{c}$ \\
\hline CVR 22 & $32.80 \mathrm{a}$ & $30.92 \mathrm{~b}$ & $28.85 \mathrm{c}$ & $42.38 \mathrm{c}$ \\
\hline AP-533 & $33.68 \mathrm{a}$ & $28.21 \mathrm{c}$ & $36.30 \mathrm{a}$ & $46.11 \mathrm{~b}$ \\
\hline SVR-0453 & $30.75 \mathrm{~b}$ & $29.68 \mathrm{~b}$ & $31.37 \mathrm{~b}$ & $43.22 \mathrm{c}$ \\
\hline Kátia & $34.39 \mathrm{a}$ & $30.01 \mathrm{~b}$ & $37.66 \mathrm{a}$ & $48.17 \mathrm{a}$ \\
\hline CV (\%) & 3.94 & 4.89 & 5.64 & 2.68 \\
\hline W & 0.60 & 0.37 & 0.26 & 0.28 \\
\hline $\mathrm{F}$ & 0.05 & 0.38 & 0.06 & 0.008 \\
\hline
\end{tabular}

${ }^{1}$ averages followed by the same letters in the column do not differ by Scott-Knott probability test at 5\%; ${ }^{2}$ lines CVR Plant Breeding Ltda. Experimental Hybrids (AP-533, SVR-0453:

Seminis do Brasil and Kátia: Hazera Seeds). W, F: assumptions of the tests Saphiro-Wilk and Levene, bold values indicate residues with normal distribution and homogenous variance. 
Lycopene has a fundamental role in tomato's red color (Soares \& Rangel, 2012; Li et al., 2013; Preczenhak et al., 2014; Khairi et al., 2015). Carvalho et al. (2005) state that the higher the levels of component $\mathrm{a}^{\star}$, higher are the levels of lycopene. Fruits with higher amounts of lycopene and other bioactive compounds, such as carotenes and phenolic compounds are important for industrial processing. These components compensate the reduction of antioxidant activity caused by chemical, physical and biological factors (Siddiqui et al., 2015).

The positive number for the chromatic descriptor $b^{*}$ indicates strong influence of yellow, being connected to the amount of $\beta$-carotenes. Carotene quantity present in tomatoes is associated to the quantity of light intercepted by the fruit (Gautier et al., 2008), with variations depending on the cultivar (Grolier et al., 2001). Lines CVR 5 and CVR 21 (Table 2) have presented higher levels of $b^{*}$, of 33.0 and 32.67, respectively, indicating fruits with slightly yellow pigmentation. They differ from lines CVR 3 (25.42), CVR 4 (27.34), CVR 8 (27.38) and the hybrid AP-533 (28.21) which have presented lower values regarding this parameter, indicating less yellow fruits.

Regarding luminosity, a difference $(\mathrm{p}<0.01)$ was verified (Table 2) between the hybrids Kátia, AP-533 and the other genotypes. The fruits of these hybrids presented higher luminosity, being the values of 37.66 and 36.30 , respectively. The lines CVR3, CVR 4 and CVR 8 presented fruits with lower values of luminosity, being these of 23.64, 23.32 and 21.26, respectively.

Araujo et al. (2014) evaluated different tomato cultivars in natura found in the genotypes analyzed, IAC 4, IAC 6, Neptune and Bari, the italian group values for $L^{*}$ of $56.90 ; 46.50$; 48.20 and 53.02, respectively. While the cultivars of Santa Cruz group have reported the coordinates of $\mathrm{L}^{*}$ in IAC 1 of 49.90 ; IAC 5 of 51.59, HTV 0601 of 49.32 and 46.56 for Débora Victory. These values are above those obtained in this study. This difference can be related to the particularities of the genetic material, as well as their genetic potential and climatic conditions of the region.

A difference $(\mathrm{p}<0.01)$ was observed (Table 2$)$ in the chromaticity between the Kátia hybrid and the other genotypes.
The Kátia hybrid showed a higher value for the parameter chroma $\left(C^{*}\right)$ when compared to the others, consequently being the material with fruits of more intense coloration and higher purity. The lines CVR 3, CVR 4 and CVR 8 exhibited pale fruits.

The saturation of the color is related with the concentration of the coloring element. Thus, higher value for the $\mathrm{C}^{\star}$ parameter denotes more pure and stronger colors, while smaller values how more mixed colors (Alessi, 2010). So it is possible to infer that hybrids Kátia followed by AP-533 are the genotypes with the higher amount of lycopene and carotene, which are responsible for the red color in tomato fruits.

Araujo et al. (2014) quantified $C^{*}$ values for cultivar IAC 4 of 34.70; IAC 6 of 28.27; Netuno of 21.22 and 27.12 for Bari. For IAC 1 it was observed the value of 34.40; in IAC 5 of 28.51, in HTV 0601 of 29.67 and 32.19 in Débora Victory. The values found in this study were superior than those obtained by Araujo et al. (2014), showing fruits with a more pronounced red color than the ones analyzed by the authors, with the lowest value for this parameter observed in the CVR 4 line (36.06) followed by CVR 8 (34.71) and CVR 3 (34.77) and the highest values observed in the Kátia hybrid (48.17).

Distinction between the genotypes were observed for mass character, transversal diameter (TD) and longitudinal diameter (DL) of the fruits (Table 3), indicating the possibility of selection. Fruits from the CVR 1 line and the AP-533, SVR-0453 and Kátia hybrids presented the highest fruit mass, while the CVR 4 and CVR 21 lines presented the lowest mass fruits. The CVR 1 line exhibited fruits with higher TD and the line CVR 21 presented the fruits with smaller TD. Hybrids AP-533 and Kátia presented the fruits with the larger longitudinal diameters and the lines CVR 3, CVR 4, CVR 5, CVR 8 and CVR 21 presented the fruits with lower DL. All the genotypes presented fruits with oblong shape (longitudinal diameter larger than the transversal).

The longer oblong fruits are generally preferred by costumers rather than the round fruits (Nascimento et al., 2013). The oblong shape of the tomato is classified in three size classes according to their TD. The fruits with TD higher than $60 \mathrm{~mm}$ belong

Table 3. Mass and transverse (DT) and longitudinal (DL) diameters evaluation of industrial tomato fruits.

\begin{tabular}{cccc}
\hline Materials $^{2}$ & Mass $^{1}(\mathrm{~g})$ & $\mathrm{DT}^{1}(\mathrm{~mm})$ & $\mathrm{DL}^{1}\left(\mathrm{~mm}^{2}\right)$ \\
\hline CVR 1 & $82.01 \mathrm{a}$ & $49.19 \mathrm{a}$ & $61.33 \mathrm{c}$ \\
CVR 3 & $66.39 \mathrm{c}$ & $47.19 \mathrm{~b}$ & $52.44 \mathrm{e}$ \\
CVR 4 & $59.22 \mathrm{~d}$ & $44.03 \mathrm{c}$ & $53.87 \mathrm{e}$ \\
CVR 5 & $72.57 \mathrm{~b}$ & $47.93 \mathrm{~b}$ & $56.33 \mathrm{~d}$ \\
CVR 8 & $67.09 \mathrm{c}$ & $47.12 \mathrm{~b}$ & $52.32 \mathrm{e}$ \\
CVR 21 & $53.31 \mathrm{~d}$ & $42.15 \mathrm{~d}$ & $52.69 \mathrm{e}$ \\
CVR 22 & $63.37 \mathrm{c}$ & $44.34 \mathrm{c}$ & $57.44 \mathrm{~d}$ \\
AP-533 & $83.32 \mathrm{a}$ & $47.15 \mathrm{~b}$ & $70.26 \mathrm{a}$ \\
SVR-0453 & $78.56 \mathrm{a}$ & $46.93 \mathrm{~b}$ & $64.25 \mathrm{~b}$ \\
Kátia & $79.90 \mathrm{a}$ & $44.93 \mathrm{c}$ & $70.71 \mathrm{a}$ \\
CV $\%)$ & 6.25 & 2.25 & 2.44 \\
W & $\mathbf{0 . 6 4}$ & $\mathbf{0 . 1 7}$ & $\mathbf{0 . 6 4}$ \\
F & $\mathbf{0 . 1 8}$ & $\mathbf{0 . 3 6}$ & $\mathbf{0 . 4 3}$ \\
\hline
\end{tabular}

${ }^{1}$ averages followed by the same letters in the column do not differ by Scott-Knott probability test at 5\%; ${ }^{2}$ lines CVR Plant Breeding Ltda. Experimental Hybrids (AP-533, SVR-0453: Seminis do Brasil and Kátia: Hazera Seeds).W, F: assumptions of the tests Saphiro-Wilk and Levene, bold values indicate residues with normal distribution and homogenous variance. 
to the large class, the TD ranging from $50 \mathrm{~mm}$ to $60 \mathrm{~mm}$ are medium and those with TD between $40 \mathrm{~mm}$ and $50 \mathrm{~mm}$ are classified as small (Brasil, 2002). In this study all the fruits are considered of small size.

Schwarz et al. (2013) analyzing different hybrids of trailing tomato observed the average mass of the fruit ranging between $50.3 \mathrm{~g}$ to $99.9 \mathrm{~g}$. These differences in the mass results obtained by these authors and the results on this study can be attributed to differences in the genotypes and the environment in which the studies were conducted.

Souza et al. (2012) reported in homozygous lines of tomato the positive and significant phenotypic correlation coefficient of 0.732 between the average fruit weight and the TD. While the genotype correlation coefficient between the average weight of the fruits and the TD was 0.858 . These data corroborate those found in this study, in which the material that presented higher mass, also showed higher TD and LD.

The comprehension of the biochemistry related to the softening of the fruits during the ripening process, provides important information about the durability of the product, and fruits with higher firmness resist longer periods of commercialization (Ramos et al., 2013). It was observed (Table 4) difference $(p<0.01)$ between analyzed genotypes for firmness of its fruits. Os genótipos CVR 1, CVR 8, Katia, CVR 22, CVR 3, AP-533 and CVR 21 destacaram-se com frutos mais firmes quando comparados aos frutos produzidos por CVR 4, CVR 5 and SVR-0453. The values of the fruits of greater firmness varied between 9.13 and $14.46 \mathrm{~N} \mathrm{~mm}^{-2}$.

According to the values presented in Table 4, the fruits of this study fall under the "soft" classification $(10 \mathrm{~N})$ and "moderately soft" (10 to 15 N) (Cantwell, 2004). Fruits placed in this second classification have higher firmness, this being one of the most important attributes related to the quality of the fruit for in natura consumption and consumer preference.

Table 4. Texture evaluation in tomatos for insdustrial processing.

\begin{tabular}{cc}
\hline Cultivars $^{2}$ & Firmness $^{1}\left(\mathrm{~N} \mathrm{~mm}^{-2}\right)$ \\
\hline CVR 1 & $11.89 \mathrm{a}$ \\
CVR 3 & $13.18 \mathrm{a}$ \\
CVR 4 & $9.13 \mathrm{~b}$ \\
CVR 5 & $11.06 \mathrm{~b}$ \\
CVR 8 & $12.18 \mathrm{a}$ \\
CVR 21 & $14.46 \mathrm{a}$ \\
CVR 22 & $13.17 \mathrm{a}$ \\
AP-533 & $13.74 \mathrm{a}$ \\
SVR-0453 & $10.01 \mathrm{~b}$ \\
Kátia & $12.48 \mathrm{a}$ \\
CV $(\%)$ & 10.79 \\
W & $\mathbf{0 . 0 7}$ \\
F & $\mathbf{0 . 6 2}$
\end{tabular}

${ }^{1}$ averages followed by the same letters in the column do not differ by Scott-Knott probability test at 5\%; ${ }^{2}$ lines CVR Plant Breeding Ltda. Experimental Hybrids (AP-533, SVR-0453: Seminis do Brasil and Kátia: Hazera Seeds). W, F: assumptions of the tests Saphiro-Wilk and Levene, bold values indicate residues with normal distribution and homogenous variance.
According to Causse et al. (2003) consumers prefer fruits of intermediary firmness.

The firmness is desirable at the mechanized harvest, implying in less damage to the fruits in this operation. That characteristic grants resistance against mechanical damages during transportation, which for industrial fruit is usually done in bulk. The fruits of soft consistency usually are deformed during transport, occurring disruption of the skin and release the cell juice, causing fermentation, deterioration and loss of industrial output (Soares \& Rangel, 2012). The tomato whit firm skin, are resistant to handling and have better capacity of conservation when compared to thin or soft skin (Chitarra \& Chitarra, 2005).

\section{Conclusions}

All the genotypes, regarding their physicochemical characteristics, produce fruits available for in natura consumption. The lines CVR 3, CVR 8 and CVR 22 are indicated for genetic improvement of the industrial tomato for hybrids creation. These produce fruits have lower $\mathrm{pH}$, marked red coloration and higher acidity, which reduce the demand of energy on the sterilization process. All genotypes analyzed produce oblong fruits, meeting the preference of the consumer of the fruit in natura. The fruits produced by the CVR 4 line are soft. The other genotypes produce fruits of intermediary firmness, these being the largest consumer preference for in natura consumption.

\section{Acknowledgements}

The authors thank CVR Plant Breeding, the field staff of the Federal University of Goiás, Bayer CropScience and Capes for the support given.

\section{References}

Alessi, E. S. (2010). Tomate seco obtido por energia solar e convencional a partir de mini-tomates congelados (Dissertação de mestrado). Escola Superior de Agricultura Luiz de Queiroz, Universidade de São Paulo, Piracicaba.

Alvarenga, M. A. R., \& Coelho, F. S. (2013). Valor nutricional. In M. A. R. Alvarenga (Ed.), Tomate: produção em campo, casa de vegetação e hidroponia (Cap. 2, pp. 25-28). Lavras: Editora Universitária de Lavras.

Anthon, G. E., \& Barrett, D. M. (2012). Pectin methylesterase activity and other factors affecting $\mathrm{pH}$ and titratable acidity in processing tomatoes. Food Chemistry, 132(2), 915-920. http://dx.doi.org/10.1016/j. foodchem.2011.11.066.

Anthon, G. E., Lestrange, M., \& Barrett, D. M. (2011). Changes in pH, acids, sugars and other quality parameters during extended vine holding of ripe processing tomatoes. Journal of the Science of Food and Agriculture, 91(7), 1175-1181. PMid:21384370. http://dx.doi. org/10.1002/jsfa.4312.

Araujo, J. C., Silva, P. P. M., Telhado, S. F. P., Sakai, R. H., Spoto, M. H. F., \& Melo, P. C. T. (2014). Physico-chemical and sensory parameters of tomato cultivars grown in organic systems. Horticultura Brasileira, 32(2), 205-209. http://dx.doi.org/10.1590/S0102-05362014000200015.

Association of Official Analytical Chemists - AOAC. (2010). Official Methods of Analysis of Association of Official Analytical Chemists (18th ed.). Gaithersburg: AOAC International. 
Barankevicz, G. B., Novello, D., Resende, J. T. V., Schwarz, K., \& Santos, E. F. (2015). Características físicas e químicas da polpa de híbridos de tomateiro, durante o armazenamento congelado. Horticultura Brasileira, 33(1), 7-11. http://dx.doi.org/10.1590/S0102-053620150000100002.

Barrett, D. M., Weakley, C., Diaz, J. V., \& Watnik, M. (2007). Qualitative and nutritional differences in processing tomatoes grown under commercial organic and conventional production systems. Journal of Food Science, 72(9), C441-451. PMid:18034702. http://dx.doi. org/10.1111/j.1750-3841.2007.00500.x.

Beckles, D. M. (2012). Factors affecting the postharvest soluble solids and sugar content of tomato (Solanum lycopersicum L.) fruit. Postharvest Biology and Technology, 63(1), 129-140. http://dx.doi. org/10.1016/j.postharvbio.2011.05.016.

Boiteux, L. S., Fonseca, M. E. N., Giordano, L. de B., \& Melo, P. C. T. (2012). Melhoramento genético. In F. M. V. T. Clemente \& L. S. Boiteux (Ed.), Produção de tomate para processamento industrial (Cap. 2, pp. 31-50). Brasília: Embrapa.

Borguini, R. G., \& Silva, M. V. (2005). Características físico-químicas e sensorias do tomate (Lycopersicon esculentum) produzido por cultivo orgânico em comparação ao convencional. Journal of Food and Nutrition, 16(4), 355-361.

Bourne, M. C. (2002). Food texture and viscosity: concept and measurement (2. ed.). San Diego: Academic Press.

Brasil. Ministério da Agricultura, Pecuária e Abastecimento. (2002, March 6). Propõe o regulamento técnico de identidade e qualidade para classificação do tomate (Portaria SARC nº 085, de 6 de março). Diário Oficial [da] República Federativa do Brasil.

Cantwell, M. (2004). Fresh-cut vegetables - Postharvest Horticulture (Series, n. 10). USA: University of California.

Carvalho, W., Fonseca, M. E. N., Silva, H. R., Boiteux, L. S., \& Giordano, L. B. (2005). Estimativa indireta de teores de licopeno em frutos de genótipos de tomateiro via análise colorimétrica. Horticultura Brasileira, 232(3), 819-825. http://dx.doi.org/10.1590/S010205362005000300026.

Causse, M., Buret, M., Robini, K., \& Verschave, P. (2003). Inheritance of nutritional and sensory quality traits in fresh market tomato and relation to consumer preferences. Journal of Food Science, 68(7), 2342-2350. http://dx.doi.org/10.1111/j.1365-2621.2003.tb05770.x.

Cemeroglu, B., Karadeniz, F., \& Ozkan, M. (2003). Meyve sebze isleme teknolojisi. Gida Teknolojisi Yayınları, 28, 469-472.

Chitarra, M. I. F., \& Chitarra, A. B. (2005). Fatores pré-colheita e colheita. In M. I. F. Chitarra \& A. B. Chitarra (Eds.), Pós-colheita de frutas e hortaliças. Fisiologia e manuseio (Cap. 4, pp. 203-282). Lavras: UFLA.

Doménech-Carbó, A., Domínguez, I., Hernández-Muñoz, P., \& Gavara, R. (2015). Electrochemical tomato (Solanum lycopersicum L.) characterisation using contact probe in situ voltammetry. Food Chemistry, 172, 318-325. PMid:25442560. http://dx.doi.org/10.1016/j. foodchem.2014.09.066.

Domínguez, I., Ferreres, F., Del Riquelme, F. P., Font, R., \& Gil, M. I. (2012). Influence of preharvest application of fungicides on the postharvest quality of tomato (Solanum lycopersicum L.). Postharvest Biology and Technology, 72, 1-10. http://dx.doi.org/10.1016/j. postharvbio.2012.04.010.

Doorenbos, J., \& Kassam, A. H. (1979). Yield response to water (FAO Irrigation and Drainage Paper, 33, 193 p.). Rome: FAO.

Dumas, Y., Dadomo, M., Di Lucca, G. D., \& Grolier, P. (2003). Review: Effects of environmental factors and agricultural techniques on antioxidant content of tomatoes. Journal of the Science of Food and Agriculture, 83(5), 369-382. http://dx.doi.org/10.1002/jsfa.1370.
Empresa Brasileira de Pesquisa Agropecuária - EMBRAPA. (2013). Sistema Brasileiro de Classificação de Solos (6. ed.). Brasília: Embrapa.

Erba, D., Casiraghi, M. C., Ribas-Agustí, A., Cáceres, R., Marfà, O., \& Castellari, M. (2013). Nutritional value of tomatoes (Solanum lycopersicum L.) grown in greenhouse by different agronomic techniques. Journal of Food Composition and Analysis, 31(2), 245251. http://dx.doi.org/10.1016/j.jfca.2013.05.014.

Ferreira, S. M. R. (2004). Características de qualidade do tomate de mesa (Lycopersicon esculentum Mill.) cultivado nos sistemas convencional e orgânico comercializado na região metropolitana de Curitiba (Tese de doutorado). Universidade Federal do Paraná, Curitiba.

Figàs, M. R., Prohens, J., Raigón, M. D., Fita, A., García-Martinez, M. D., Casanova, C., Borràs, D., Plazas, M., Andújar, I., \& Soler, S. (2015). Characterization of composition traits related to organoleptic and functional quality for the differentiation, selection and enhancement of local varieties of tomato from different cultivar groups. Food Chemystri, 187, 517-524. PMid:25977058. http://dx.doi.org/10.1016/j. foodchem.2015.04.083.

Gatta, G., Libutti, A., Gagliardi, A., Beneduce, L., Brusetti, L., Borruso, L., Disciglio, G., \& Tarantino, E. (2015). Treated agro-industrial wastewater irrigation of tomato crop: effects on qualitative/quantitative characteristics of production and microbiological properties of the soil. Agricultural Water Management, 149, 33-43. http://dx.doi. org/10.1016/j.agwat.2014.10.016.

Gautier, H., Diakou-Verdin, V., Bénard, C., Reich, M., Buret, M., Bourgaud, F., Poëssel, J. L., Caris-Veyrat, C., \& Génard, M. (2008). How does tomato quality (sugar, acid, and nutritional quality) vary with ripening stage, temperature, and irradiance? Journal of Agricultural and Food Chemistry, 56(4), 1241-1250. PMid:18237131. http://dx.doi.org/10.1021/jf072196t.

Grolier, P., Bartholin, G., Broers, L., Caris-Veyrat, C., Dadomo, M., Di Lucca, G., Dumas, Y., Meddens, F., Sandei, L., \& Schuch, W. (2001). Composition of tomatoes and tomato products in antioxidants. In R. Bilton, M. Gerber, P. Grolier \& C. Leoni (Eds.), The White book on antioxidants in tomatoes and tomato products and their health benefits (Chap. 1, pp. 1-104). Avignon: CMITI.

Ilahy, R., Hdider, C., Lenucci, M. S., Tlili, I., \& Dalessandro, G. (2011). Antioxidant activity and bioactive compound changes during fruit ripening of high-lycopene tomato cultivars. Journal of Food Composition and Analysis, 24(5), 588-595. http://dx.doi.org/10.1016/j. jfca.2010.11.003.

Instituto Adolfo Lutz - IAL. (2008). Métodos físico-químicos para análise de alimentos. São Paulo: IAL.

Jarquín-Enríquez, L., Mercado-Silva, E. M., Maldonado, J. L., \& LopezBaltazar, J. (2013). Lycopene content and color index of tomatoes are affected by the greenhouse cover. Scientia Horticulturae, 155, 43-48. http://dx.doi.org/10.1016/j.scienta.2013.03.004.

Kavitha, P., Shivashankara, K. S., Rao, V. K., Sadashiva, A. T., Ravishankar, K. V., \& Sathish, G. J. (2014). Genotypic variability for antioxidant and quality parameters among tomato cultivars, hybrids, cherry tomatoes and wild species. Journal of the Science of Food and Agriculture, 94(5), 993-999. PMid:24037905. http://dx.doi.org/10.1002/jsfa.6359.

Khairi, A. N., Falah, M. A. F., Suyantohadi, A., Takahashi, N., \& Nishina, H. (2015). Effect of storage temperatures on color of tomato fruit (Solanum lycopersicum Mill.) cultivated under moderate water stress treatment. Agriculture and Agricultural Science Procedia, 3, 178-183. http://dx.doi.org/10.1016/j.aaspro.2015.01.035.

Li, H., Deng, Z., Liu, R., Loewen, S., \& Tsao, R. (2013). Carotenoid compositions of coloured tomato cultivars and contribution to antioxidant activities and protection against $\mathrm{H}_{2} \mathrm{O}_{2}$-induced cell 
death in H9c2. Food Chemistry, 136(2), 878-888. PMid:23122140. http://dx.doi.org/10.1016/j.foodchem.2012.08.020.

Mohammed, A. E., Smit, I., Pawelzik, E., Keutgen, A. J., \& Horneburg, B. (2012). Organically grown tomato (Lycopersicon esculentum Mill.): bioactive compounds in the fruit and infection with Phytophthora infestans. Journal of the Science of Food and Agriculture, 92(7), 1424-1431. PMid:22162026. http://dx.doi.org/10.1002/jsfa.4720.

Nascimento, A. R., Soares, M. S. Jr., Caliari, M., Fernandes, P. M., Rodrigues, J. P. M., \& Carvalho, W. T. (2013). Qualidade de tomates de mesa cultivados em sistema orgânico e convencional no estado de Goiás. Horticultura Brasileira, 31(4), 628-635. http://dx.doi. org/10.1590/S0102-05362013000400020.

Preczenhak, A. P., Resende, J. T. V., Chagas, R. R., Silva, P. R., Schwarz, K., \& Morales, R. G. F. (2014). Caracterização agronômica de genótipos de minitomate. Horticultura Brasileira, 32(2), 348-356. http://dx.doi.org/10.1590/S0102-053620140003000018.

Quilot-Turion, B., \& Causse, M. (2014). Natural diversity and genetic control of fruit sensory quality. In P. Nath, M. Bouzayen, A. K. Mattoo \& J. C. Pech (Eds.), Fruit ripening: physiology, signalling and genomics (Cap. 14, pp. 228-245). Croydon: CAB International.

Ramos, A. R. P., Amaro, A. C. E., Macedo, A. C., Sugawara, G. S. A., Evangelista, R. M., Rodrigues, J. D., \& Ono, E. O. (2013). Qualidade de frutos de tomate 'giuliana' tratados com produtos de efeitos fisiológicos. Semina: Ciências Agrárias, 34(6), 3543-3552. http:// dx.doi.org/10.5433/1679-0359.2013v34n6Supl1p3543.

Riahi, A., Hdider, C., Sanaa, M., Tarchoun, N., Ben Kheder, M., \& Guezal, I. (2009). Effect of conventional and organic production systems on the yield and quality of field tomato cultivars grown in Tunisia. Journal of the Science of Food and Agriculture, 89(13), 2275-2282. http://dx.doi.org/10.1002/jsfa.3720.

Rocha, M. C., Deliza, R., Corrêa, F. M., Carmo, M. G. F., \& Abboud, A. C. S. (2013). A study to guide breeding of new cultivars of organic cherry tomato following a consumer-driven approach. Food Research International, 51(1), 265-273. http://dx.doi.org/10.1016/j. foodres.2012.12.019.
Rosales, M. A., Cervilla, L. M., Sánchez-Rodríguez, E., Rubio-Wilhelmi, M. D. M., Blasco, B., Ríos, J. J., Soriano, T., Castilla, N., Romero, L., \& Ruiz, J. M. (2011). The effect of environmental conditions on nutritional quality of cherry tomato fruits: evaluation of two experimental Mediterranean greenhouses. Journal of the Science of Food and Agriculture, 91(1), 152-162. PMid:20853276. http:// dx.doi.org/10.1002/jsfa.4166.

Schwarz, K., Resende, J. T. V., Preczenhak, A. P., Paula, J. T., Faria, M. V., \& Dias, D. M. (2013). Desempenho agronômico e qualidade físico-química de híbridos de tomateiro em cultivo rasteiro. Horticultura Brasileira, 31(3), 410-418. http://dx.doi.org/10.1590/ S0102-05362013000300011.

Siddiqui, M. W., Ayala-Zavala, J. F., \& Dhua, R. S. (2015). Genotypic variation in tomatoes affecting processing and antioxidant attributes. Critical Reviews in Food Science and Nutrition, 55(13), 1819-1835. PMid:24279355. http://dx.doi.org/10.1080/10408398.2012.710278.

Silva, E. C., Alvarenga, P. P. M., \& Maciel, G. M. (2013). Avaliações físicoquimicas de frutos de tomateiro em função de doses de potássio e nitrogênio. Bioscience Journal, 29(6), 1788-1795.

Silva, J. B. C., Giordano, L. B., Furumoto, O., Boiteux, L. S., França, F. H., Bôas, G. L. V., Branco, M. C., Medeiros, M. A., Marouelli, W., Silva, W. L. C., Lopes, C. A., Ávila, A. C., Nascimento, W. M., \& Pereira, W. (2003). Cultivo de tomate para industrialização. Brasília: Embrapa Hortaliças. Retrieved from: https://sistemasdeproducao.cnptia. embrapa.br/FontesHTML/Tomate/TomateIndustrial/index.htm

Soares, B. B., \& Rangel, R. (2012). Aspectos industriais da cultura. In F. M. V. T. Clemente \& L. S. Boiteux (Eds.), Produção de tomate para processamento industrial (Cap. 15, pp. 331-344). Brasília: Embrapa.

Souza, L. M., Melo, P. C. T., Luders, R. R., \& Melo, A. M. T. (2012). Correlations between yield and fruit quality characteristics of fresh market tomatoes. Horticultura Brasileira, 30(4), 627-631. http:// dx.doi.org/10.1590/S0102-05362012000400011.

Tigist, M., Workneh, T. S., \& Woldetsadik, K. (2013). Effects of variety on the quality of tomato stored under ambient conditions. Journal of Food Science and Technology, 50(3), 477-486. PMid:24425942. http://dx.doi.org/10.1007/s13197-011-0378-0. 